\title{
Seasonal variation on diet of juvenile Elops saurus Linnaeus, 1766 (Ladyfish) in the Parnaiba River Delta
}

\author{
Variação sazonal na dieta dos jovens de Elops saurus Linnaeus, 1766 (Ubarana) no Delta \\ do Rio Parnaíba
}

Tatiane Araujo Santos ${ }^{1}$ (D), Thamires Souza Gonçalves ${ }^{1}$ (D), Patricia Silva do Nascimento ${ }^{1}$ (D), Cézar Augusto Freire Fernandes ${ }^{1}$ (D) and Francisca Edna de Andrade Cunha ${ }^{1 *}$

${ }^{1}$ Universidade Federal do Piauí - UFPI, Campus de Parnaíba, Av. São Sebastião, 2819, Nossa

Senhora de Fátima, CEP 64202-020, Parnaíba, PI, Brasil

*e-mail: f_edna@yahoo.com.br

Cite as: Santos, T.A. et al. Seasonal variation on diet of juvenile Elops saurus Linnaeus, 1766 (Ladyfish) in the Parnaiba River Delta. Acta Limnologica Brasiliensia, 2020, vol. 32, e11.

Abstract: Aim: Identify seasonal variations in the diet of juvenile living in the estuary of the Parnaíba River Delta. Methods: Food items were identified through analysis of stomach contents, and later submitted to analysis by regular methods for Frequency of Occurrence (FO), Frequency Numerical (FN), Gravimetric Frequency (FW) and Relative Importance Index (IRI). Results: Juvenile diet of Elops saurus that inhabit the lagoons in the Parnaíba delta was composed in order decreasing of importance by Osteichthyes (Teleostei), Insecta and Crustacea in addition to Polychaeta and Nematoda. It was also observed a high frequency of occurrence of fragments of plastics in the diet. In the rainy season, 17 items were recorded in the diet, whereas in the dry season only 7 items were present. Relative Importance Index showed high presence of the Teleostei fish (69.93\%) on diet of E. saurus during the rainy season, whereas during the dry period the insects of the families Corixidae (43.25\%) and Dysticidae (39.16\%). Conclusions: With the study it was possible to identify that juvenile are piscivorous in the rainy season when there is a higher availability of prey in the environment and insectivores in the dry season when it reduces the supply of food, indicating feeding flexibility to environmental alterations.

Keywords: feeding; carnivory; feeding flexibility; Elops saurus.

Resumo: Objetivo: Identificar variaçóes sazonais na dieta de jovens que vivem no estuário do Delta do Rio Parnaíba. Métodos: Os itens alimentares foram identificados através da análise do conteúdo estomacal, e depois submetidos à análise pelos métodos Frequência de Ocorrência (FO), Frequência Numérica (FN), Frequência gravimétrica (FW) e Índice de Importância Relativa (IRI). Resultados: A dieta dos jovens de Elops saurus que habitam as lagoas no delta do Parnaíba foi composta em ordem decrescente de importância por Osteichthyes (Teleostei), Insecta e Crustacea, além de Polychaeta e Nematoda. Também foi registrada elevada frequência de ocorrência de fragmentos de plásticos na dieta. Na estação chuvosa, 17 itens foram registrados na dieta, enquanto que na estação seca apenas 7 itens estavam presentes. O Índice de Importância Relativa evidenciou a importância dos peixes Teleostei $(69,93 \%)$ na dieta de E. saurus na estação chuvosa, enquanto que, no período Seco destacaram-se os insetos das Famílias Corixidae (43,25\%) e Dysticidae (39,16\%). Conclusóes: Com o estudo foi possível identificar que os jovens são carnívoros, especificamente, piscívoros na estação chuvosa quando ocorre maior disponibilidade de presas no ambiente e insetívoros na estação seca, quando reduz a oferta de alimento, evidenciando uma flexibilidade alimentar frente às alteraçóes ambientais.

Palavras-chave: alimentação; carnivoria; flexibilidade alimentar; Elops saurus. 


\section{Introduction}

The Parnaiba Delta is formed by approximately 90 continental islands, located in Brazilian Northeastern coast, encompassing the states of Piauí, Ceará and Maranhão. Also knowledge as the only delta in the Americas that empties into the open sea (Guzzi, 2012). Estuaries are the mainly nurseries habitats composed by streams, islands, bays, marginal lagoons and wetlands, in which a large number of species are found, representing essential habitats for feeding, growing and reproduction for many fisheries resources (Bittencourt, 2009). Among the fishery resources in the Parnaiba River delta several species of crustaceans and fish with high commercial value belonging to the families Centropomidae, Sciaenidae, Mugilidae, Ariidae, etc. (Farias et al., 2015).

The Elopiformes order also occurs in the area being represented by the Elopidae and Megalopidae families (Farias et al., 2015). Representatives of these families live in marine and estuarine environments, rarely found in freshwater sites, occurring in tropical and subtropical seas (Adams et al., 2013), in Atlantic and Pacific Oceans (Froese \& Pauly, 2018). The species Elops saurus Linnaeus, 1766 is the only representative of the Elopidae family with distribution on all Brazilian coast (Hildebrand, 1963), where it is most common in the North and Northeast regions of the country, being popularly known as Ubarana.

The delta ecosystem of the Parnaiba River presents high habitat complexity due to the canals (Igarapés), 90 islands, mangrove vegetation and lagoons whose seasonal connectivity depends on the tidal regime and the rainy season. The occurrence of juvenile of several species of the ichthyofauna of the Parnaiba River was recorded in the lagoons, characterizing this habitat as a nursery used as a shelter and feeding area by these juvenile. In this context, the objective was to know the food resources exploited by these juvenile, as well as the interference of seasonal variables in the diet of juvenile of E. saurus while remaining in the wetlands.

\section{Material and Methods}

The study area is located in the Parnaíba River Delta Estuary, where two marine protected areas (Parnaíba Delta Marine Extractive Reserve and Environmental Protection Area) are located between the States of Maranhão and Piauí, at coordinates $02^{\circ} 45^{\prime} 59^{\prime \prime}$ 'S and $41^{\circ} 50^{\prime} 41^{\prime \prime} \mathrm{W}$ (Figure 1). The collections were carried out in marginal lagoons (Salgadas, Poldros, Coqueiro and Caju) through the use of hand trawls nets (Picaré), during the development of the Common Snook project, in cooperation with Rare (Brazil) and UFPI, in the period July/2016 to May/2017. Monthly data of the rainfall were obtained from the agrometeorological station of the Instituto Nacional de Meteorologia (INMET, 2018), located in the Embrapa Meio-Norte, Parnaíba-PI. The regional climate is tropical dry (as, according to the Köppen classification) and is characterized by two distinct seasons: a rainy summer and a dry winter, with average annual air temperature of $30^{\circ} \mathrm{C}$ and rainfall of $1,200 \mathrm{~mm}$.

The specimens of $E$. saurus that occur in the lagoons of the Parnaiba River Delta ware considered in the juvenile stage based Jones et al. (1978) that determined standard length between $35-258 \mathrm{~mm}$ and McBride et al. (2001) were found juveniles with total length $>50-400 \mathrm{~mm}$.

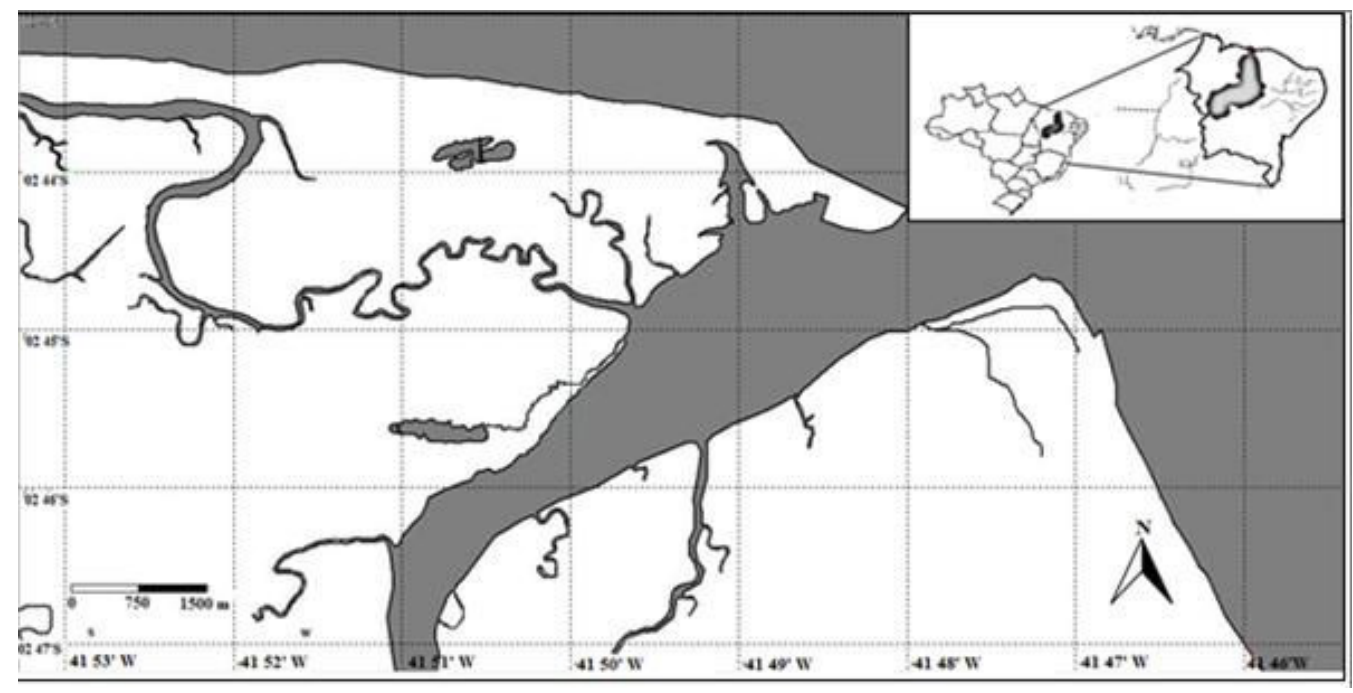

Figure 1. Study area highlighting the location of the Parnaiba River Delta Estuary. 
Fishes were transported to the Laboratory of Ichthyology of the Federal University of Piaui (LABIC) submitted to biometry to obtain weight and total length followed by dissection, to remove the stomach that was fixed in $10 \%$ formalin solution for 24 hours and later preserved in alcohol $70 \%$.

The analysis of the stomach contents was aided by Stereomicroscope and surgical materials, being carried out the taxonomy of the best preserved items followed by the steps of counting and weighing in analytical balance ( $0.001 \mathrm{~g}$ precision). The unidentified content was grouped into a category called remains, which was composed of fragments of organic material from the macro-categories (Osteichthyes, Crustacea and Insecta), hair strands, and vegetables. Due to the high frequency of occurrence of plastics were considered as item in the analysis.

\subsection{Data analysis}

The degree of stomach repletion was analyzed by the relation of stomach weight and total weight of the fish, both were measured in grams (Zavala-Camin, 1996).

The data were analyzed using the qualitative methods of Occurrence Frequency (Hynes, 1950; Hyslop, 1980), and quantitative Numerical and Gravimetric Frequency (Hynes, 1950; Hyslop, 1980). Methods were combined in the Relative Importance index proposed by Pinkas et al. (1971), which was expressed as a percentage, to order by importance the diet items of $E$. saurus juvenile.

\section{Results}

The mean monthly rainfall presented significant variations (Kruskal-Wallis, $\mathrm{H}=139, \mathrm{p}=0.00$ ), with the highest averages recorded in February and April with 138 and $118 \mathrm{~mm}$, respectively, resulting in higher rainfall in the rainy season $125.48 \mathrm{~mm}$ and in the dry season $19.19 \mathrm{~mm}$ ( $\mathrm{T}$ test: $-19.287, \mathrm{p}<0.01$ ).

121 juveniles were analyzed, total length varied between 12.9 to $30.5 \mathrm{~cm}$ and a total weight of 14 to $98 \mathrm{~g}$ (Figure 2). During the study period, there was no monthly variation of the total length for fishes (Anova, $\mathrm{F}=2.278, \mathrm{p}>0.05$ ) and total weight (Anova, $\mathrm{F}=1,882, \mathrm{p}>0.05)$. For the data grouped in dry and rainy season, there was no significant difference for weight ( $T$ test: $0.827, \mathrm{p}=0.409)$ and length ( $\mathrm{T}$ test: $1.333, \mathrm{p}=0.184)$ of the individuals analyzed.

Juvenile diet of Elops saurus that inhabit the lagoons in the Parnaíba delta showed carnivorous behavior with tendency to piscivorous due to prey availability in the habitat. Diet was composed in order decreasing of importance by Osteichthyes
(Teleostei), Insecta and Crustacea in addition to Polychaeta and Nematoda (Figure 3). It was also observed a high frequency of occurrence of fragments of plastics in the diet (Figure 3).

Among the categories of food items, the high gravimetric frequency of the fish and the numerical value of the insects and crustaceans were observed, showing a balance between the frequency of occurrence of fish and insects (Figure 3).

Seasonal variation analysis on diet of Elops saurus was based from 94 stomachs of the fish collected during rainy season and 24 in the dry season, among which 118 had some content and only 3 were empty. The degree of stomach repletion did not show significant variation during the monitored months (ANOVA, $\mathrm{F}=2.187, \mathrm{p}=0.059$ ) and season ( $T$ test: $-0.3313, \mathrm{p}=0.741$ ).

In the rainy season, 17 items were recorded in the diet, whereas in the dry season only 7 items were present, with Ophichthydae, Gobiidae, Gerreidae, Sciaenidae, Eleotridae and Haemulidae, Cameroon Penaeidae and Insects of the Blatodea Family

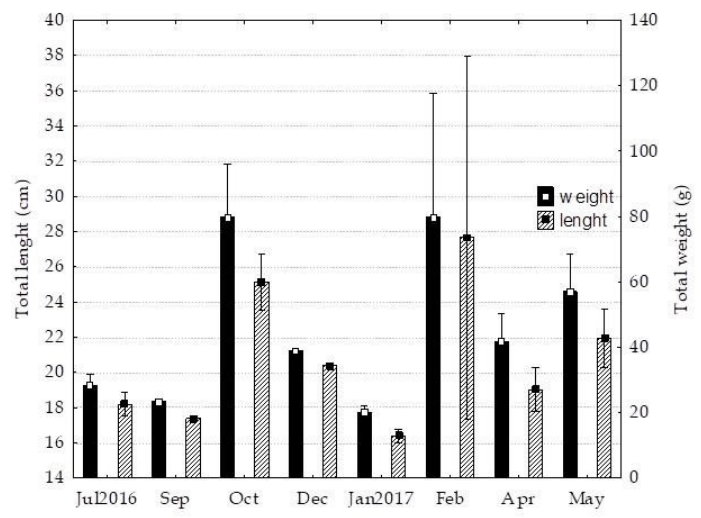

Figure 2. Mean ( \pm std. dev.) of the Total weight and Total length of Elops saurus juvenile on the Parnaiba Delta River in the period between July (2016) to May (2017).

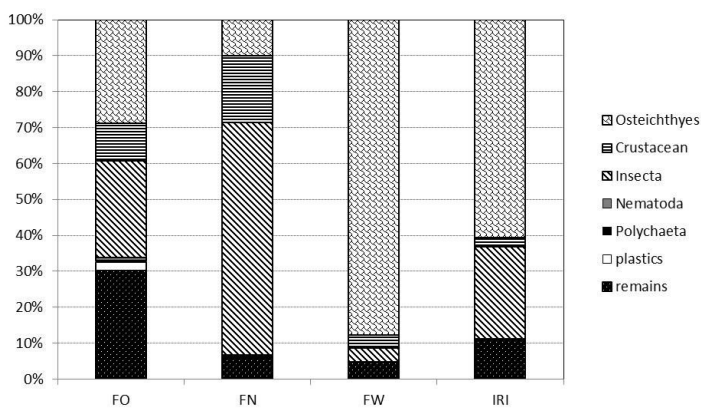

Figure 3. Food items of juvenile Elops saurus in Delta do Rio Parnaíba (PI) between July 2016 and April 2017. Frequency of occurrence (FO), Frequency numerical (FN), Frequency Gravimetric (FW) e Relative Importance Index (IRI). 
absent. of Polychaeta and Nematoda (Table 1). The occurrence of plastics in the diet was recorded only in the rainy season (Table 1). Osteichthyes were more frequent in the rainy season $(36.71 \%)$, while in the dry season insects $(64.40 \%)$ were affected by the Corixidae and Distycidae families, both with 27.12\% (Table 1).
In the numerical frequency, the diet presented similarities between the rainy season, with the insects Corixidae (33.15\%) and Amphipod microcrustaceans $(18.71 \%)$, while in the dry season the insect families Corixidae (49.25\%) and Dysticidae (41.92\%) (Table 1, Figure 4) although the Corixidae Family was more abundant in the dry season.

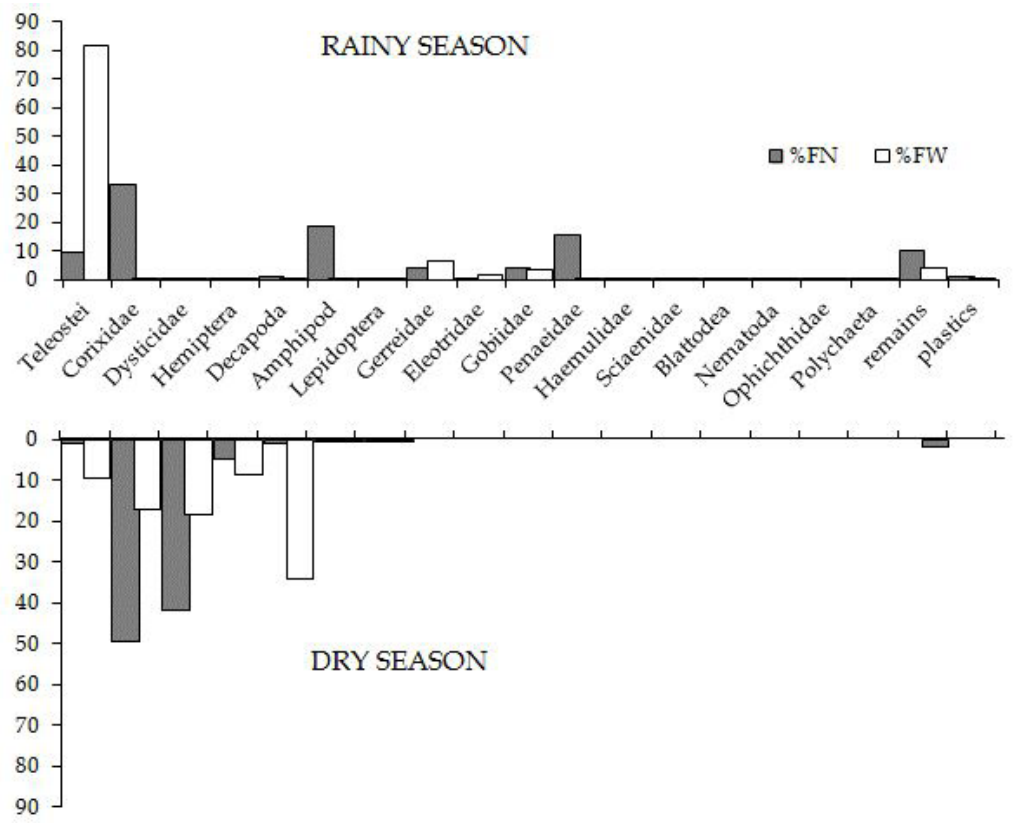

Figure 4. Frequency numerical (FN) and Gravimetric (FW) on diet of juvenile Elops saurus in the Parnaiba Delta River in the period between July (2016) to May (2017).

Table 1. Seasonal analysis for Frequency of occurrence (FO\%), Frequency numerical (FN\%), Frequency Gravimetric (FW\%) e Relative Importance Index (\%IRI) on diet of Elops saurus in Delta do Rio Parnaíba (PI) between July 2016 and April 2017.

\begin{tabular}{|c|c|c|c|c|c|c|c|c|}
\hline \multirow{2}{*}{ ITEMS } & \multicolumn{2}{|c|}{ FO\% } & \multicolumn{2}{|c|}{ FN\% } & \multicolumn{2}{|c|}{ FW\% } & \multicolumn{2}{|c|}{ \%IRI } \\
\hline & Rainy & Dry & Rainy & Dry & Rainy & Dry & Rainy & Dry \\
\hline Osteichthyes & 36.71 & 8.47 & 18.90 & 0.94 & 93.74 & 9.41 & 72.43 & 2.11 \\
\hline Teleostei & 25.95 & 8.47 & 9.80 & 0.94 & 81.66 & 9.41 & 69.93 & 2.11 \\
\hline Ophichthidae & 0.63 & 0.00 & 0.18 & 0.00 & 0.00 & 0.00 & 0.00 & 0.00 \\
\hline Gobiidae & 1.90 & 0.00 & 4.28 & 0.00 & 3.56 & 0.00 & 0.44 & 0.00 \\
\hline Gerreidae & 6.33 & 0.00 & 4.10 & 0.00 & 6.70 & 0.00 & 2.01 & 0.00 \\
\hline Sciaenidae & 0.63 & 0.00 & 0.18 & 0.00 & 0.10 & 0.00 & 0.01 & 0.00 \\
\hline Eleotridae & 0.63 & 0.00 & 0.18 & 0.00 & 1.51 & 0.00 & 0.03 & 0.00 \\
\hline Haemulidae & 0.63 & 0.00 & 0.18 & 0.00 & 0.21 & 0.00 & 0.01 & 0.00 \\
\hline Crustacea & 10.76 & 10.16 & 35.12 & 1.13 & 1.25 & 34.22 & 4.35 & 7.14 \\
\hline Amphipod & 6.96 & 1.69 & 18.72 & 0.19 & 0.42 & 0.13 & 3.93 & 0.01 \\
\hline Penaeidae & 0.63 & 0.00 & 15.51 & 0.00 & 0.37 & 0.00 & 0.30 & 0.00 \\
\hline Decapoda & 3.16 & 8.47 & 0.89 & 0.94 & 0.45 & 34.09 & 0.13 & 7.12 \\
\hline Insecta & 12.89 & 64.40 & 34.77 & 96.06 & 0.80 & 44.42 & 8.24 & 85.14 \\
\hline Corixidae & 8.23 & 27.12 & 33.16 & 49.25 & 0.54 & 17.24 & 8.17 & 43.25 \\
\hline Dysticidae & 0.63 & 27.12 & 0.36 & 41.92 & 0.03 & 18.28 & 0.01 & 39.16 \\
\hline Hemiptera & 1.27 & 8.47 & 0.53 & 4.70 & 0.02 & 8.59 & 0.02 & 2.70 \\
\hline Blattodea & 0.86 & 0.00 & 0.19 & 0.00 & 0.07 & 0.00 & 0.01 & 0.00 \\
\hline Lepidoptera & 1.90 & 1.69 & 0.53 & 0.19 & 0.14 & 0.31 & 0.04 & 0.02 \\
\hline Polychaeta & 0.63 & 0.00 & 0.18 & 0.00 & 0.00 & 0.00 & 0.00 & 0.00 \\
\hline Nematoda & 1.27 & 0.00 & 0.36 & 0.00 & 0.01 & 0.00 & 0.01 & 0.00 \\
\hline Plastics & 3.16 & 0.00 & 0.89 & 0.00 & 0.00 & 0.00 & 0.08 & 0.00 \\
\hline Remains & 35.44 & 16.95 & 9.98 & 1.88 & 4.28 & 0.00 & 14.89 & 5.62 \\
\hline
\end{tabular}


Gravimetric frequency showed large differences with the predominance of the Teleostei Fish $(81.66 \%)$ in the rainy season, whereas in the dry season they were insects (44.04\%), Crustaceans and Decapoda (34.09\%) (Table 1, Figure 4).

Relative Importance Index showed high presence of the Teleostei fish $(69.93 \%)$ on diet of $E$. saurus during the rainy season, whereas during the dry period the insects of the families Corixidae (43.25\%) and Dysticidae (39.16\%) (Table 1, Figure 4).

\section{Discussion}

The juvenile of E. saurus that occur in the lagoons of the Parnaiba River Delta are present all year round and always in the juvenile phase, of around $200 \mathrm{~mm}$. The length observed in the present study may be related to the fishing equipment used, which may have influenced the capture of juvenile stage, since the apparatus may act selectively in the capture. According to Thompson \& Deegan (1982), the species in the juvenile phase is eurialine, which can be found in estuarine habitats of low salinity, but can also be found in brackish estuaries and juvenile are common in hypersaline bays and lagoons (Cervigón et al., 1992) .

Juvenile diet of Elops saurus that inhabits the lagoons in the Delta of the river Parnaiba presented carnivorous food habit, with tendency to piscivory, but also fed on crustaceans and insects. Similar results to that found by Hiatt (1947), Odum \& Heald (1972), Santos-Martinez \& Arboleda (1993) and Smith (1997) registered a carnivorous habit, where diet composition was based on small fish, crustaceans and some aquatic insects, in addition to sometimes crop residues. In other studies they recorded a diet exclusively piscivorous (Sekavec, 1971; Zale \& Merrifield, 1989).

Seasonally, the diet of the species in the rainy season presented a greater diversity of food items but with a predominance of fishes (Teleostei), while in the dry season there was reduction in the diversity of food items and predominance of aquatic Insects. These characteristics in the rainy season are due to the increase in the water and organic matter supply, as well as, the expansion of the connectivity between the diverse habitats like marginal lagoons, canals and islands of the ecosystem propitiating a greater supply of prey mainly for fish in the rainy season. Also the use of the habitat for feeding and reproduction from fish species in Delta of Parnaiba, due increase in prey abundance for larvae and juvenile (Barletta et al. 2017). According to the studies of Peret (2004), the animals that feed on fish have a food plasticity, that is, they can adapt to the environment conditions and feed from what is available. Cunha (2017) found similar fish species composition and seasonal variation for Weakfish acoupa Cynoscion acoupa diet in the region.

In the dry season there is a decrease in the diversity and abundance of prey due to the loss of connectivity, being reflected in adaptations with predominance of insects belonging to the families Corixidae and Dysticidae. Although insects are also important in rainy season, but more easy prey in dry season due low fish abundance in Delta. Bernardo et al. (2012) have shown that the distribution of these insects is related to the physical-chemical characteristics of habitats, where they prefer higher temperature waters and low turbidity and the availability of food resources. Insects are extremely important in the feeding of aquatic organisms, since they have a high nutritional content (Wallace \& Merritt, 1980), besides being present in great abundance in the marginal lagoons, an environment that shelters many species of fish, among them $E$. saurus.

In this study it was possible to observe that the diet of E. saurus is based mainly on fish, insects and crustaceans with high level of feeding plasticity depend on prey abundance in the environment (Dantas et al., 2015). However, diet of some species is based on the mentioned items; studies such as those of Thompson et al. (2004), Browne et al. (2008) and Ryan et al. (2009) showed that the ingestion of plastic micro-particles, known as pellets may be present in the stomachs of these animals. Micro-particles are originated through chemical, physical and biological processes that act in the disintegration of plastic materials. Occurrence of plastics in the diet of juvenile of E. saurus also occurred seasonally, being associated to the rainy season, probably accidentally ingested during the capture of benthic prey (zoobenthos) that occurred exclusively in the rainy season, such as Penaeidae, Polychaeta and Nematoda shrimps, as well as increase of Amphipod micro-crustaceans. Pollution and environment degradation still increase in estuarine habitat due many human activities (e.g. metal, micro plastic and absence of basic sanitation), reducing ecosystem capacity to produce resource and maintain services (Barletta \& Lima, 2019). 


\section{Acknowledgements}

We thank financial support agency RARE Brazil through the Fish Forever program. We would like to thank all those who helped with the field work.

\section{References}

ADAMS, A.J., HORODYSKY, A.Z., MCBRIDE, R.S., GUINDON, K., SHENKER, J., MACDONALD, T.C., HARWELL, H.D., WARD, R. and CARPENTER, K. Global conservation status and research needs for tarpons (Megalopidae), ladyfishes (Elopidae) and bonefishes (Albulidae). Fish and Fisheries, 2013, 8(2), 1-32.

BARLETTA, M. and LIMA, A.R.A. Systematic review of fish ecology and anthropogenic impacts in South American estuaries: setting priorities for ecosystem conservation. Frontiers in Marine Science, 2019, 6, 237. http://dx.doi.org/10.3389/fmars.2019.00237.

BARLETTA, M., LIMA, A.R.A., DANTAS, D.V., OLIVEIRA, I.M., NETO, J.R., FERNANDES, C.A.F., FARIAS, E.G.G., FILHO, J.L.R. and COSTA, M.F. How can accurate landing stats help in designing better fisheries and environmental management for western atlantic estuaries? In: C.W. FINKL and C. MAKOWSKI, eds. Coastal wetlands: alteration and remediation. Cham: Springer; 2017, pp. 631-703. http://dx.doi.org/10.1007/978-3-31956179-0_20.

BERNARDO, L.P., RIBEIRO, J.R.I., STENERT, C. and MALTCHIK, L. Uma nova espécie de Sigara Fabricius (Hemiptera, Heteroptera, Corixidae) e redescrição das espécies do gênero com registro no Estado do Rio Grande do Sul, Brasil. Revista Brasileira de Entomologia, 2012, 56(2), 159-182. http://dx.doi. org/10.1590/S0085-56262012005000032.

BITTENCOURT, V.F.N. 2009 Proteção a pesca do Robalo (Centropomus parallelus) na Foz do Rio Mambucada, Angra dos Reis-RJ. Revista Educação Ambiental, 2009, BE-597(2), 38-43.

BROWNE, M.A., DISSANAYAKE, A., GALLOWAY, T.S., LOWE, D.M. and THOMPSON, R.C. Ingested microscopic plastic translocates to the circulatory system of the mussel, Mytilus edulis(L). Environmental Science \& Technology, 2008, 42(13), 5026-5031. http://dx.doi.org/10.1021/es800249a. PMid:18678044.

CERVIGÓN, F.R., CIPRIANI, W.F., GARIBALDI, L., HENDRICKX, M., LEMUS, A.J., MÁRQUEZ, R., POUTIERS, J.M., ROBAINA, G. and RODRIGUEZ, B. Fichas FAO de identificación de especies para los fines de la pesca: guía de campo de las especies comerciales marinas y de aquas salobres de la costa septentrional de Sur América. Rome: FAO, 1992, $513 \mathrm{p}$.

CUNHA, F.E.A. Feed and trophic morpholgy of yellow Hake Cynoscion acoupa (Lacèpede, 1801) in the
Northeast Brazil. Canadian Journal of Pure and Applied Sciences, 2017, 11, 4079-4085.

DANTAS, D.V., BARLETTA, M. and COSTA, M.F. Feeding ecology and seasonal diet overlap between Stellifer brasiliensis and Stellifer stellifer in a tropical estuarine ecocline. Journal of Fish Biology, 2015, 86(2), 707. http://dx.doi.org/10.1111/jfb.12592.

FARIAS, A.C.S., FONTELES FILHO, A.A., CORRÊA IVO, C.F., FERNANDES, C.A.F. and CUNHA, F.E.A. Cadeia produtiva da pesca no interior do Delta do Parnaiba e área marinha adjacente. Fortaleza: RDS, 2015, 240 p.

FROESE, R. and PAULY, D., eds. FishBase [online]. 2018 [viewed 19 June 2018]. Available from: https:// www.fishbase.org

GUZZI, A. Biodiversidade do Delta do Parnaíba: litoral piauiense. Parnaíba: EDUFPIP, 2012, 466 p.

HIATT, R.W. Food-chains and the food cycle in Hawaiian fish ponds. Part I: the food and feeding habits of mullet (Mugil cephalus), milkfish (Chanos chanos), and the ten-pounder (Elops machnata). Transactions of the American Fisheries Society, 1947, 74(1), 250-261. http://dx.doi.org/10.1577/15488659(1944)74[250:FATFCI]2.0.CO;2.

HILDEBRAND, S.F. Family Elopidae: fishes of the Western North Atlantic: part three. New Haven: Sears Foundation for Marine Research, Yale University, 1963, pp. 111-131.

HYNES, H.B.N. The food of fresh-water sticklebacks (Gasterosteus aculeatus and Pygosteus pungitius), with a review of methods used in studies of the food of fishes. Journal of Animal Ecology, 1950, 19(1), 36-58. http://dx.doi.org/10.2307/1570.

HYSLOP, E.J. Stomach contents analysis: a review of methods and their application. Journal of Fish Biology, 1980, 17(4), 411-429. http://dx.doi. org/10.1111/j.1095-8649.1980.tb02775.x.

INSTITUTO NACIONAL DE METEOROLOGIA - INMET [online]. Brasília, 2018 [viewed 20 Mar. 2018]. Available from: www.inmet.gov.br

JONES, P.W., MARTIN, F.D. and HARDY JUNIOR, J.D. Development of fishes of the Mid-Atlantic Bight: an atlas of eggs, larval and juvenile stages. Washington: U.S. Fish and Wildlife Service, 1978. vol. 1. Acipenseridae through Ictaluridae.

MCBRIDE, R.S., MCDONALD, T.C., MATHESON, R.E., RYDENE, D.A. and HOOD, P.B. Nursery habitats for ladyfish, Elops saurus, along salinity gradients in two Florida estuaries. Fishery Bulletim, 2001, 99, 443-458.

ODUM, W.E. and HEALD, E.J. Trophic analyses of an estuarine mangrove community. Bulletin of Marine Science, 1972, 22(3), 671-738.

PERET, A.M. Dinâmica da alimentação de peixes piscivoros da represa de Três Marias (MG) [Dissertação de Mestrado em Ecologia e Recursos Naturais]. São Carlos: Universidade Federal de São Carlos, 2004. 
PINKAS, L., OLIPHANT, M.S. and IVERSON, I.L.K. Food habits of albacore, bluefin tuna, and bonito in California waters. Sacramento: Department of and Game, 1971. Fish Bulletin, no. 152.

RYAN, P.G., MOORE, C.J., VAN FRANEKER, J.A. and MOLONEY, C.L. Monitoring the abundance of plastic debris in the marine environment. Philosophical Transactions of the Royal Society of London. Series B, Biological Sciences, 2009, 364(1526), 1999-2012. http://dx.doi.org/10.1098/ rstb.2008.0207. PMid:19528052.

SANTOS-MARTINEZ, A. and ARBOLEDA, S. Aspectos biológicos y ecológicos del macabí Elops saurus Linnaeus (Pisces: Elopidae) en la Cienaga Grande de Santa Marta y costa adyacente, Caribe Colombiano. Anales del Instituto de Investigaciones Marinas de Punta de Betín, 1993, 22(1), 77-96.

SEKAVEC, G.B. Gross morphology of the digestive tract of the ladyfish, Elops saurus. Chesapeake Science, 1971, 12(4), 275-276. http://dx.doi.org/10.2307/1350916.

SMITH, D.G. Elopidae: ladyfishes, tenpounders. In: K.E. CARPENTER and V.H. NIEM, eds. FAO species identification guide for fishery purposes: the living marine resources of the Western Central Pacific. Rome: Food and Agriculture Organizations of the United Nations, 1997, pp. 1619-1620. vol. 3. Batoid fishes, chimaeras and bony fishes. Part 1 (Elopidae to Linophrynidae).
THOMPSON, B.A. and DEEGAN, L.A. Distribution of ladyfish (Elops saurus) and bonefish (Albula vulpes) leptocephali in Louisiana. Bulletin of Marine Science, 1982, 32(4), 936-939.

THOMPSON, R.C., OLSEN, Y., MITCHELL, R.P., DAVIS, A., ROWLAND, S.J., JOHN, A.W.G., MCGONIGLE, D. and RUSSELL, A.E. Lost at sea: where is all the plastic? Science, 2004, 304(5672), 838-838. http://dx.doi.org/10.1126/ science.1094559. PMid:15131299.

WALLACE, J.B. and MERRITT, R.W. Filter-feeding ecology of aquatic insects. Annual Review of Entomology, 1980, 25(1), 103-132. http://dx.doi. org/10.1146/annurev.en.25.010180.000535.

ZALE, A.V. and MERRIFIELD, S.G. Species profiles: life histories and environmental requirements of coastal fishes and invertebrates (South Florida), Ladyfish and Tarpon. US Fish and Wildlife Service Biological Report, 1989, 82, 11-104.

ZAVALA-CAMIN, L.A. Introdução aos estudos sobre alimentação natural em peixes. Maringá: EDUEM, 1996, $129 \mathrm{p}$.

Received: 10 December 2018 Accepted: 27 April 2020

Associate Editors: Antonio Fernando Monteiro Camargo 